\title{
Conclusion
}

\section{Combining Social Capital with Learned Capital: Competing on Different Imperial Paths}

Our long history began in medieval Bologna, where mastery of canon law and Roman civil law turned a small number of cosmopolitan elites into elite legal professionals. This was a process of empowering family capital with new knowledge. It required financial resources. Only an advantaged few had the ability to travel and to pay the costs; only they had the background to succeed in the rigorous academic work required for a doctorate from Bologna. The graduates put their social and scholarly capital to work in the in-fighting between canon law and civil law, controversies over feudal privileges, and disputes within and among the multiplicity of jurisdictions existing at that time. Growing trade and commerce made the graduates of schools of law very much in demand. As Brundage (2008) noted, they went from "strength to strength" during the medieval period.

The expertise of the small group of law graduates trained in civil and canon law, and their successful application of it, thus became central to the conversion of the old landed elite into modern-day professionals and ultimately agents and leaders of newly created states and companies. The descendants of this formative periodable to mobilize the habitus established by then of family capital, cosmopolitan scholarly learning (initially Roman civil law and Roman Catholic canon law), and proximity to power-remain keys to understanding continuity amid the constant reinvention of hierarchies, norms, and institutions of different legal fields. The continuity of the story makes that habitus of internalized behavior relevant and quite visible today.

The case studies in Part IV show the importance of relatively small cosmopolitan legal elites able to maintain their positions over time across dramatic political and social changes, including independence and global legal revolutions, most recently and notably the neoliberal revolution arising from the end of the Cold 
War and the rise of US hegemony. The revolution has had varying degrees of success in the countries we have examined in this book. One clear result is that large corporate law firms have proliferated where they had not existed before, including in the countries studied here. Also, there is greater emphasis on meritocratic capital to obtain positions in such firms, even if the ability to succeed according to meritocratic criteria relates strongly to social class.

The corporate law firms started outside the cores of the local legal professions but have since found strong places within local hierarchies and co-opted their major opponents. Also, albeit to different degrees, the second phase of the legal revolution reveals the development of very close ties between the relatively small elite of corporate lawyers in magic circles, red circles, and big fours or fives, and an equally small number of elite law schools-together they build and reinforce the great distance between the mass of law graduates and an ever wealthier few. The new and reformed law schools compete for international status, and they also compete to place their graduates in corporate firms. Reforms oriented toward corporate law firms include more engaged teaching, a focus on practical problem-solving, and a new emphasis on subjects such as mergers and acquisitions. Related reforms have enhanced the visibility of interdisciplinary research and more generally the sophisticated interdisciplinary arguments that the most elite firms employ.

We now reflect on the scholarly approaches we have drawn upon and what our own approach brings. The case studies, as noted earlier, well exemplify and continue the model that Brundage and Martines portrayed of the legal profession as it emerged in medieval Italy and developed with the rise of the city-states. Lawyers served from the beginning as brokers combining arcane cosmopolitan knowledge with family capital in various ways, and they used their position to build law and states in relation to emerging economic groups, the Church, and the huge number of jurisdictions under feudalism.

The case studies also fit generally with Berman's theory of legal revolution. We interpret that theory as a theory of permanent revolutions-the rebooting of legal establishments through the challenges brought by aspiring quasi-elites as they made new investments in knowledge and linked themselves to emerging political powers. That process is quite evident in the contrast we drew between South Korea and Japan. A certain sector of South Korea's legal profession, linked to US approaches and human rights initiatives, acquired power through an alliance with its country's democracy movement (which was not necessarily pro-US) against the formerly authoritarian government and its supporters. That alliance led to very different outcome in South Korea than in Japan in terms of legal education and the power of the traditional professional hierarchies. We see various forms of political legal alliances working toward the legal revolution in India as well as China, and there are hints that aspiring legal elites were key actors within the legal profession in these battles. These case studies also bear out Bourdieu's observation that the 
class and family capital that undergirds the power of cosmopolitan elites is reinforced through meritocratic criteria and links to state power.

It is important to recognize, however, that legal revolutions are more complex than Berman's theory and our narratives that draw on it. These revolutions involve constantly shifting positions and blended categories such as professor/politician in the United States and prosecutor/NGO/ entrepreneur in South Korea. Nevertheless, Berman's theory provides a solid hypothesis for how legal establishments wedded to existing power change and endure in relation to new social movements. The emerging legal revolution leads to more or less significant changes while rebuilding the position of law close to power and refurbishing the established legal hierarchies that had been tied to an earlier status quo. Lauren Benton and Lisa Ford's Rage for Order (2016), which we also draw upon, shows how the British Empire built law out of a relationship between London and the local or expatriate imperial agents designated as representatives of a law connecting Britain to its colonies and noncolonial outposts.

The problématiques employed by Berman, Bourdieu, and Benton and Ford, from our perspective, miss how larger geopolitical dimensions shape the circulation of ideas and the particular mixes of social and learned capital that we find in different settings. Benton and Ford help explain the approach adopted in the British Empire, but they do not address how the larger geopolitics affects interconnected histories in different places and through changes in imperial power. In medieval times, competition and complementarity characterized not only the tensions between learned capital and social capital, but also the role of feudal justice, communal approaches, and many other approaches to dispute resolution. Interaction with these and other localized approaches helped produce a divergence relatively early in the post-medieval history of the legal profession.

The British combination of learned and social capital emerged through the transformation of local justices of the peace into learned gentlemen with different political alliances than found in medieval or Renaissance Italy. Social capital to mediate between the Crown, the aristocracy, and the gentry combined with learned law, but social capital dominated-as evidenced by the role of the Inns of Court, especially after the seventeenth century, as mainly dining clubs where apprentices were socialized into the bar. As Benton and Ford show (2016), when the British exported their approach to colonies, they exported the same focus on social capital. They sought out locals endowed with social capital, such as the Brahmins and the Parsi, and encouraged or facilitated their education-mainly through dining with members of the bar-then sent them back to India as quasiEnglish gentlemen. On the basis of their social capital and a little learned capital, they were able to profit tremendously. They became the "nabobs of the law."

The other model that emerged and that is important in our case studies also required social/familial capital and learned capital, but it also maintained the prominent role of selection through schools and education that characterized 
the Bologna model, which produced aristocrats as grand professors in the Holy Roman Empire and Continental Europe. That model's relative valuation of scholarly capital was not inconsistent with the booms and busts related to times of relative obsolescence in the value of scholarly capital, such as in the history of the French noblesse de robe. Similar conditions of devaluation drove the revival that took place in Prussia in the eighteenth century, which included a purge of the lawyer-courtiers serving and dependent on the aristocracy. The private bar shrank, and scholarly and educational standards improved. German legal education maintained its prestige but also became oriented toward the production of bureaucrats and statespersons. Professors were also circumscribed somewhat by the development of codification, but the mix of social and scholarly capital was still very different from that of the British. The Prussian investment in law and the state then became central to the well-known state-led industrialization spearheaded by Prussia in the nineteenth century in an effort to catch up to the British, who were a century ahead.

At the end of the nineteenth century, heightened imperial competition led to extraordinary investments in legal expertise in colonial governance and legitimacy. The revival of law during the Indian Raj is one example; the cultivation of the Javanese aristocrats sent by the Dutch to Leiden for their education is another. The earlier gradual process accelerated as a function of imperial competition. What the British exported into India, as noted, was based largely on social capital; it empowered Brahmins and Parsi, in particular, as gentlemen lawyers. Leiden-trained Javanese aristocrats in Indonesia were a similar example in a Dutch colony. This phenomenon was not evident in Hong Kong, an exception because expatriates occupied the relatively few places in the legal profession.

This second geopolitical approach we see in the case studies can be viewed as a "catch-up" strategy both in the North, exemplified by Germany and France, and in the South, exemplified in our case studies by China, Japan, and South Korea. Those from the leading samurai clans in Japan invested in the state and followed the Prussian model of a strong state legitimated by legally trained bureaucrats, with judges and lawyers coming from less powerful samurai clans and given more subordinate roles. Codes designed in part to limit the role of private lawyers and judges were mimicked as well. For China and Japan, this was clearly part of an economic catch-up strategy and a push to gain credibility in the West, and the Japanese brought that strategy to Korea. This strategy did not necessarily allow those most endowed with social capital to reap the rewards of learned legal capital akin to those enjoyed by the Indian nabobs of the law, but the investment of ambitious reformers diffused that state-oriented legal capital throughout these Asian contexts.

The third geopolitical approach central to this study is the one connected to the United States. There were British-trained barristers in the colonies, and they in turned trained others. This small cosmopolitan elite played a strong role 
in US independence and governance. Its ties to Britain and British legal expertise, however, led to attacks on lawyers in the Jacksonian period and a low point for lawyers' prestige. There was a boom for the elite of the legal profession later in the nineteenth century that went with an upgrading of legal education led by Harvard, which drew in part on the formalism of the Continental model. This helped the partners of the emerging corporate law firms become lawyer-statespersons and not simply hired guns for the robber barons. Those partners then internationalized, exporting an anti-imperial imperialism into the Philippines and elsewhere as the basis for a "legalist empire."

The particular blend of social and learned capital has differed in each of the settings we have examined. We find similar cycles of booms, busts, and revivals, but those cycles vary as to timing, the spaces of activity, and the direction of the circulation of people and knowledge. The colonial legal and social capital associated with the Indian Brahmin lawyers, for example, grew as a result of the political capital accumulated from the independence movement, then contracted when elite lawyers resisted Nehru's social reforms.

Booms and busts can lead to new hegemonies, an example being the evolution from the Jacksonian rejection of the Toquevillian lawyer-aristocrat; to the corporate lawyer statesperson armed with an upgraded legal discourse, close relationships with a few elite law schools, and ties to powerful corporate and individual clients and the philanthropic foundations they founded with their clients' money. They became the basis of the foreign policy establishment (FPE) that, with relatively minor ups and downs, thrived at least into the 1970 .

The FPE's approach led to the law and development movement as a new form of export of moral imperialism and scholarly selectivity. That movement sought to develop lawyer-statespersons to open up economies and invest in moderate social reform. The key goals were legal education reform and the development of the tools wielded by US "first-rate metropolitan lawyers." It failed in part because of the weakness of the liberal establishment in the United States, which found itself divided over the Vietnam War. The main reason, however, was resistance from the South. The investment that was imported by or poured into India and Japan (then to South Korea), in particular, in the late nineteenth century resulted in legal professions with bunker mentalities that resisted reform as threats to the status and rewards enjoyed by those at the top.

The shape of the resistance related to the geopolitics of the nineteenth century. India's elite bench and bar mobilized the social and family capital central to their status and practice. Japan and South Korea mobilized the quasi-family capital that grew out of their respective "cradles of the legal mafia" in the Judicial Research and Training Institute in South Korea and the Legal Research and Training Institute in Japan, which trained those few who succeeded in passing the bar examination. Ties to conservative economic and political power also helped maintain the legal status quo. Bar passage into the select group entering the training institutes came 
from mastery of the codes, which meant "excelling in memorization, requiring one to in effect 'memorize all the textbooks and theories"' about the codes.

In China, by contrast, investors in foreign legal expertise began their work during an era in which classical Chinese knowledge and political expertise were devalued. Their learned investment was a survival strategy, not a defensive one, and the flexibility of the cosmopolitan legal elite today reflects the same approach.

The most recent phase of legal revolution is connected to but different from the moral imperialism of the law and development movement that was launched in India, Japan, and South Korea roughly a generation earlier. There has been a counter-offensive against the various embodiments of legal oligarchies, with different alliances in India, Japan, and South Korea. They have had some degree of success in each country. The major changes are the emphasis on corporate law firms, financial markets, and neoliberal policies. Also, there have been recent changes in legal education, including new law schools and new law degrees, more engaged and practical teaching, and more investment in interdisciplinary scholarship and discourse and in "modern" legal arguments suitable for corporate law firms. The embrace of US-style legal theory has drawn scholars around the globe into the debates and approaches that succeed in global centers, especially in the "highest ranking" law schools such as Harvard.

The revolution has enhanced meritocracy, but we see no evidence that it has opened the profession to the relatively disadvantaged, who cannot as a rule muster the resources to succeed under the meritocratic criteria. They may enter the legal profession through the schools at the bottom of the hierarchy, which are quite numerous in China and India, or through the relatively few schools at the bottom, as in Japan and South Korea. But their inability to get into the most select schools, and perhaps to gain access to a foreign LL.M. or other degree, eliminates any chance for them to join the magic circles of elite law firms and top in-house positions. The mass of lawyers is strongly separated from the small fraction at the top.

The reforms have created some meritocratic openness, however. Outsiders to legal families, for example, who come from business and professional families, may gain access to the resources to get into and succeed in a select law school. We see this especially in India. These outsiders represent some of the leaders in the legal revolution, in part because they have observed that without family capital they face a glass ceiling.

The dramatic divide in the legal profession between the few and the very many who may have law degrees but practice a very different kind of law is reminiscent of the medieval period, when only a very few could practice formalized and rarified dispute resolution under the civil law and the canon law. Looking backward, while we may exalt the rise of professionalized Roman and canon law in dispute resolution in the medieval period, we need to remember that that story coexists with a huge variation in approaches, formalities, and authorities at the same time in different areas. Since legal history tends to be by and for lawyers, there has been neglect 
of the many gradations in the boundary between what gets before the law, what is above or below the gaze of the law, and how the boundaries change. In short, there are ebbs and flows in the role of professionalized law in relation to other forms of authority, and ideally these should be subject to historical and sociological inquiry. We do not have detailed information, but there are suggestions that in China, for example, the growing importance of law in global business transactions and as a tool of regulation from the top may be very different from local dispute resolution, where social capital may be more important than legal argument. The general point is that part of the tension in legal fields-and hence instability, conflict, and reform-comes from the challenge and contestation it has to confront from the second tier of "petty" disputes and second tier of legal professionals.

There are also tensions arising from counter-developments away from the narrative of professionalization and legalization stemming from notables who seek to displace the role of law as local authority or in relation to empire and hegemony. A strong instrumentalism in the Cold War and in the War against Terror, for example, provided international leeway for local leaders to diminish the role of law. Notables in particular circumstances may ground their decisions in law, in indigenous norms, in clientelistic relationships, in religious texts, or in various mixes of these. Law identified with a hegemon who becomes an enemy might be purged. If the Maoist and peasant-led Cultural Revolution had succeeded, for example, what kind of party governance and clientelism might have replaced the role, however weak, of law in China? We cannot be sure. The legal revolutions we refer to in our analyses of the case studies have succeeded in keeping law close to power, but that result is not inevitable.

Finally, these potential challenges to the authority of professional justice raise a related complexity that we could not take up in this work. Bourdieu appropriately emphasizes the complementarity and competition between social capital and meritocratic capital in legal fields (2021). This mode of analysis also suggests a pull of social capital because those able to mobilize it can use it maintain their positions in legal fields with limited investment in scholarship and meritocracyleading to potential devaluations of scholarly capital. Bourdieu's focus on the role of social capital and legal capital did not, however, lead him to address the ways that professional justice and what we can call a kind of feudal justice continue to coexist in different ways. We have referred to dual justice, but the two sides are not separate. The concept of dual justice in the sense of a "lower" justice dominated by social capital versus a more "professionalized" justice of formal law masks this coexistence.

As E.P. Thompson in Whigs and Hunters (1975) showed, the professional justice system in the eighteenth century in Britain doled out draconian punishments for those who committed minor crimes, but he noted also that some of those convicted could mobilize mentors, notables, neighbors, or others, to gain some kind of recourse, ultimately perhaps to the Crown, suggesting that the ultimate 
resolution could stem from both formal professional justice and a kind of feudal justice drawing much more on social capital. Thompson's narrative, therefore, is not just about his famous assertion that the formal law has some autonomy despite its service to power. This additional power of social elites on the perimeter of professional justice is different. That power can modify or avoid professional justice or even mobilize professional justice on behalf of particular interests. The Trump administration provided many examples of what can be seen as the personalistic mobilization of professional law to punish enemies and reward friends. Similarly, it may be that the chaebols in South Korea still have the power, as suggested in a Korean interview, to mobilize prosecutors to target perceived critics. The connections between social capital and professional justice change in relation to evolving power relationships. An exploration of these connections would add a further dimension to studies of the relations between law, social change, and stability that could be developed in the future.

\section{CONCLUDING WORDS}

This book is ambitious, covering long interconnected histories and countries, each of which has a cadre of legal and other scholars much more knowledgeable than we can be about any single country or historical period. The terrain we seek to examine here is too large for us to master, even with the help of area legal and other experts. We have tried to use the tools of historical sociology and the best sources available to provide a novel but convincing account of a story that extends from medieval Bologna to cosmopolitan elites in imperial settings to a new legal revolution. The narratives show at a minimum that the global rise of corporate law firms is not just about the demand for such services or global isomorphism. It is about a legal revolution related to global hegemonic power, hierarchies in national legal fields created out of the older European empires, the role of challengers drawing on learned law emanating initially from the United States to build their positions and the role of scholarly law, and the resistance, embrace, or co-optation of the new by those who occupy the leading positions in legal fields. These are hardfought battles that have shaped the national credibility of law and lawyers in the competing global context.

The stories leading to the financial and neoliberal legal revolution emanating from the United States, in addition, provide an opportunity to reexamine the relationship between law and social change. We found tools for that examination by going back to the origins of the legal profession, as examined by Martines (1968) and Brundage (2008), and those tools exposed for us how the cosmopolitan broker model developed in Bologna both stayed the same and diverged in different settings, especially vis-à-vis Britain and Germany and, later, the United States. Berman's theory of legal revolution $(1983 ; 2002)$ provided a framework for examining law and social change in particular settings. Bourdieu's insistence on the 
competing and complementary relationship between social capital and learned capital and between lawyers and the state fits well with Berman. So do Bourdieu's conceptual tools such as the field and the concept of habitus. Successful legal revolutions bring change, but the change comes with continuity, often through the refurbishment of a legal establishment and the interests embedded in it.

What we especially bring in this book, we think, is a missing geopolitical dimension. What emerged within legal fields depended on imperial competition, specific developments in competing empires, and interactions with local settings. Changes, including legal revolutions, depended in large part on learned law, whose credibility stemmed from geopolitical developments, including, for example, the rise of US hegemony in the aftermath of the Cold War. Our approach makes clear that today's universe of "best practices" in legal education and legal practice must be understood in relation to the geopolitics that have made them "best." 